\section{Murine Experimental Root Canal Infection: Cytokine Expression in Response to F. nucleatum and E. faecalis}

Andressa Lamari Reis ${ }^{1}$, Ricardo Reis Oliveira ${ }^{1}$, Warley Luciano Fonseca Tavares ${ }^{1}$, Thamyris Duque Silva Saldanha1, Luiz de Macêdo Farias², Leda Quércia Vieira², Antônio Paulino Ribeiro Sobrinho ${ }^{1}$

\author{
'School of Dentistry, UFMG - \\ Universidade Federal de Minas \\ Gerais, Belo Horizonte, MG, Brazil \\ 2Institute of Biological \\ Sciences, UFMG - Universidade \\ Federal de Minas Gerais, Belo \\ Horizonte, MG, Brazil
}

Correspondence: Dr. Warley Luciano Fonseca Tavares, R. Castelo de Edimburgo 235/402, Castelo, 31330-240 Belo Horizonte, MG, Brazil. Tel: +55-31-3409-2405. e-mail: warleyt@hotmail.com

\begin{abstract}
The aim of this study was to evaluate the gene expression of proinflammatory (RANKL, TNF- $\alpha$ and IFN- $\gamma$ ) and regulatory (TGF- $\beta$ and IL-10) cytokines as reaction to experimental infection by mono or bi-association of Fusobacterium nucleatum (ATCC 10953) and Enterococcus faecalis (ATCC 19433). F. nucleatum and E. faecalis, either in mono- or bi-association were inoculated into the root canal system (RCS) of Balb/c mice. Animals were sacrificed at 10 and 20 days after infection and periapical tissues surrounding the root were collected. The mRNA expression of the cytokines RANKL, TNF- $\alpha$, IFN- $\gamma$, TGF- $\beta$ and IL-10 was assessed using real-time PCR. The Kruskal-Wallis test was used for statistical analysis. F. nucleatum mono-infection induced high expression of RANKL and TNF- $\alpha$, while its modulation was due to IL-10. High expression of IFN- $\gamma$ at day 20 was up-regulated by $E$. faecalis and RANKL; TNF- $\alpha$ was up-regulated by an independent mechanism via IL-10 and TGF- $\beta$. Bi-association ( $F$. nucleatum and $E$. faecalis) stimulated high expression of RANKL, TNF- $\alpha$ and IFN- $\gamma$, which seemed to be modulated by TGF- $\beta 20$ days later. The gene expression of proinflammatory cytokines was more prominent in the earlier periods of the experimental periapical infection, which concomitantly decreased in the later period. This expression may be regulated by IL-10 and TGF- $\beta$ in an infection-specific condition
\end{abstract}

Key Words: cytokines, Grampositive bacteria, Gram-negative bacteria, periapical lesion.

\section{Introduction}

Root canal infections lead to the development of periapical lesions. However, their development depends on the infecting microbiota as well as the host response (1).

In polymicrobial infections, synergistic or antagonistic microbial interactions play a role in the pathogenic effects of microorganisms $(2,3)$. Bacterial relationships involve different associations: among Gram-negative species and also between Gram-negative and Gram-positive species. The peptidoglycan cell wall of Gram-positive bacteria acts synergistically with lipopolysaccharides (LPS) of Gramnegative (4), complicating even more the antigenicity of the endodontic content.

Former researches have clearly demonstrated differences between Gram-positive and Gram-negative bacteria, in mono or bi-association, which induce cytokine and chemokine expression (5).

Periapical inflammatory diseases involve several aspects, such as bacterial ecology and pathogenicity, innate and adaptative immune cells, which in turn produce cytokines (1). Several proinflammatory responses, like those induced by interleukin 1 (IL-1), tumour necrosis factor-alpha (TNF- $\alpha$ ), interferon-gamma (IFN- $\gamma$ ) and the receptor activator of the nuclear factor kappa-B ligand (RANKL) may occur in periapical tissues $(6,7)$. On the other hand, antiinflammatory responses, as those induced by interleukin 4
(IL-4), interleukin 10 (IL-10) and transforming growth factor (TGF- $\beta$ ), modulate the first pro-inflammatory events (6).

LPS from Fusobacterium nucleatum is highly cytotoxic (8) whereas lipoteichoic acid from Enterococcus faecalis clinical strain promotes TNF- $\alpha$ expression by the nuclear factor kappa-B (RANK) and p38 MAPK signaling pathways in differentiated THP-1 macrophages (9).

This study checked the ability of some bacteria prevalent in human infections, F. nucleatum (Gram negative strict anaerobe) and E. faecalis (Gram positive facultative anaerobe), experimentally inoculated into root canals of conventional mice either in mono or bi-infection, to induce the proinflammatory (RANKL, TNF- $\alpha$, IFN- $\gamma$ ) and regulatory cytokines (IL-10 and TGF- $\beta$ ) in the periapical area surrounding these infections.

The tested null hypothesis was that F. nucleatum and $E$. faecalis alone or in association have no effect on the expression of RANKL, TNF- $\alpha$, IFN- $\gamma$, IL-10 and TGF- $\beta$ mRNA.

\section{Material and Methods Mice}

Thirty female 8-week-old mice were used (Balb/c, ICB, Universidade Federal de Minas Gerais, Belo Horizonte, $\underline{\mathrm{MG}}$, Brazil). All manipulations were performed under 
sterile conditions in a laminar flow hood (Veco, Campinas, $\mathrm{SP}, \mathrm{Brazil)}$. The animals were fed ad libitum. The animal ethics committee (152/2010, CETEA/UFMG) approved the experimental protocol.

\section{Experimental Root Canal Infection}

Previously described (5) experimental procedures were performed. Briefly, the animals were intraperitoneally anesthetised using $100 \mathrm{mg} \mathrm{kg}^{-1}$ ketamine hydrochloride (Dopalen, Vetbrands Animal Health, Jacareí, SP, Brazil) and $10 \mathrm{mg} \mathrm{kg}^{-1}$ xylazine (Anasedan, Agribrands do Brasil Ltda, Paulinia, SP, Brazil). The pulp chamber of the maxillary right first molar was assessed by an endodontic operative microscope (Alliance, São Paulo, SP, Brazil) and a 1/4 carbide bur (KG Sorensen, Barueri, SP, Brazil), coupled to a controlled rotation hand piece (Driller, São Paulo, SP, Brazil). Afterwards, using \# 0.8 and \# $10 \mathrm{~K}$ files, the canal was probed.

Three groups of mice were inoculated as follows: group I, F. nucleatum strains; group II, E. faecalis; and group III, F. nucleatum and E. faecalis. Ten mice were used for each experimental group per time point; time points were at 10 and 20 days after the surgical procedure.

In the control group, a provisional restorative material composed of zinc oxide and sulphate (Coltosol ${ }^{\circledR}$; Vigodent, Bonsucesso, RJ, Brazil) sealed the teeth; in the experimental groups, inoculation was performed before this sealing.

\section{Microorganisms}

The two selected bacterial strains were $F$. nucleatum (ATCC 10953) and E. faecalis (ATCC 19433). The bacteria were maintained at $-86{ }^{\circ} \mathrm{C}$; recovery was performed using a brain-heart infusion supplemented with sheep's blood, yeast extract, hemin and menadione (BHI-S; Difco, Detroit, $\mathrm{MI}$, USA). F. nucleatum was incubated in an anaerobic chamber containing an atmosphere of $85 \% \mathrm{~N}_{2}, 10 \% \mathrm{H}_{2}$, and $5 \% \mathrm{CO}_{2}$ (Forma Scientific Inc., Marietta, OH, USA) for $48 \mathrm{~h}$ and $E$. faecalis was placed in a bacteriological incubator for $24 \mathrm{~h}$. For root canal infections, the concentration of the bacteria grown in BHI-SPRAS (Difco) was adjusted to approximately $10^{7} \mathrm{CFU}$ per $25 \mu \mathrm{L}$ in the same broth in mono-infection. In bi-association, both bacteria were pooled to a total of $10^{7} \mathrm{CFU}$ per $25 \mu \mathrm{L}$.

Next, the bacterial suspensions were inoculated into the RCS by dripping, using type PPD syringes and needles. Gram staining regularly checked the purity of the microorganisms . The opening and inoculation in animals were performed in the laminar flow hood. Disinfection and antisepsis of the surgical field were performed according to Möller (10). All instruments were sterilized by autoclaving. All the chemicals were pure quality grade.

\section{Animal Sacrifice and Sample Extraction}

After 10 and 20 days, the animals were sacrificed by cervical dislocation. The periapical tissue surrounding root apices of the right and left molars was extracted together with the surrounding bone. Gingiva, oral mucosa and crown were removed and discarded (11). Samples were treated with $250 \mu \mathrm{L}$ of Trizol (GIBCO BRL Laboratories, Grand Island-NY, USA). The samples were crushed using electrical equipment (IKA T10 basic; Merse, Campinas, SP, Brazil) and stored in a $-20^{\circ} \mathrm{C}$ freezer for RNA extraction.

\section{RNA Extraction}

$200 \mu \mathrm{L}$ of chloroform were added to the Eppendorf tubes containing the samples. They were then centrifuged for $15 \mathrm{~min}$ at $12,000 \mathrm{~g}$ at $4{ }^{\circ} \mathrm{C}$, which produced the precipitation of the RNA. The aqueous phase was transferred to another Eppendorf tube, followed by the addition of $250 \mu \mathrm{L}$ isopropanol (Merck, SP, Brazil). The mixture was incubated in BOD (Q-315D; Quimis ${ }^{\circledR}$ ) at $25^{\circ} \mathrm{C}$ for $15 \mathrm{~min}$ and centrifuged for $10 \mathrm{~min}$ at $12,000 \mathrm{~g}$ at $4{ }^{\circ} \mathrm{C}$, producing the precipitation of RNA. The aqueous phase was discarded and the precipitated RNA was washed with $250 \mu \mathrm{L} 75 \%$ ethanol. The mixture was then centrifuged at $10,000 \mathrm{~g}$ at $4{ }^{\circ} \mathrm{C}$ for $15 \mathrm{~min}$. The ethanol-containing tubes were turned over and centrifuged at $10,000 \mathrm{~g}$ at $4{ }^{\circ} \mathrm{C}$ for 15 $\mathrm{min}$. The aqueous phase was discarded and the tubes were overturned for approximately $15 \mathrm{~min}$ to remove all liquid. $25 \mu \mathrm{L}$ of high-quality water treated with DEPC (diethyl pyrocarbonate; SIGMA ${ }^{\circledR}$ Chemical Co., St. Louis, MO, EUA) were added to the solution. The samples were frozen in a $-80{ }^{\circ} \mathrm{C}$ freezer.

\section{mRNA Quantification}

The solution containing the mRNA was read in a spectrophotometer (Nanodrop ${ }^{\circledR} /$ ND 1000, Wilmington, $D E$, USA) using 260/280 OD wavelength. The quantification of each sample of mRNA was obtained Using the formula [mRNA-mg/mL] $=0 D 260 \times$ dilution $\times 40$.

\section{Obtaining cDNAs}

cDNA was synthesised using $2 \mu \mathrm{g}$ of RNA by reverse transcription, as described by Silva et al. (11). The standard conditions were as follows: a holding stage of $95{ }^{\circ} \mathrm{C}$ for $10 \mathrm{~min}$; a cycling stage with 40 cycles of $95^{\circ} \mathrm{C}$ for $15 \mathrm{~s}$, $60{ }^{\circ} \mathrm{C}$ for $1 \mathrm{~min}$ and a melting curve stage of $95^{\circ} \mathrm{C}$ for 15 $\mathrm{s}, 60{ }^{\circ} \mathrm{C}$ for $1 \mathrm{~min}$ and $95{ }^{\circ} \mathrm{C}$ for $15 \mathrm{~s}$.

\section{Cytokine Detection and Quantification}

The primer sequences used for the analysis of the cytokines are in Table 1.

Real-time PCR was performed using the Step One Real-time PCR System (Applied Biosystems, Foster 
City, CA, USA). In addition, the SYBR-Green detection system (Applied Biosystems) was used to assess primer amplification. The housekeeping gene hypoxanthine phosphoribosyltransferase (HPRT) was also amplified and used to normalise mRNA expression levels. All the samples were run in duplicate in a $20 \mu \mathrm{L}$ reaction volume with $1 \mu \mathrm{g}$ cDNA. Sequence Detection Software, version v. 2.0 (Applied Biosystems) was used to analyse data after amplification. The results were obtained as threshold cycle (Ct) values, which represent the cycle number at which the fluorescence

Table 1. Primer sequence

\begin{tabular}{|c|c|c|}
\hline Genes & Sense and antisense & $\mathrm{bp}^{*}$ \\
\hline HPRT & $\begin{array}{l}\text { FW: GTTGGATACAGGCCAGACTTTGTT } \\
\text { RV: GATTCAACTTGCGCTCATCTTAGGC }\end{array}$ & 162 \\
\hline TNF- $\alpha$ & $\begin{array}{l}\text { FW: ATCTTCTCAAAATTCGAGTGACCA } \\
\text { RV: TGGAGTAGACAAGGTACAACCC }\end{array}$ & 171 \\
\hline TGF- $\beta$ & $\begin{array}{l}\text { FW: TGACGTCACTGGAGTTGTACG } \\
\text { RV: GGTTCATGTCATGGATGGTGC }\end{array}$ & 169 \\
\hline RANKL & $\begin{array}{c}\text { FW: CATCCCATCGGGTTCCATAA } \\
\text { RV: CCTTAGTTTTCCGTTGCTTAACGAC }\end{array}$ & 103 \\
\hline IL-10 & $\begin{array}{l}\text { FW: GGTTGCCAAGCCTTATCGGA } \\
\text { RV: ACCTGCTCCACTGCCTTGCT }\end{array}$ & 109 \\
\hline IFN- $\gamma$ & $\begin{array}{l}\text { FW: CAAGTGGCATAGATGTGGAAGAA } \\
\text { RV: TGGCTCTGCAGGATTTTCATG }\end{array}$ & 90 \\
\hline
\end{tabular}
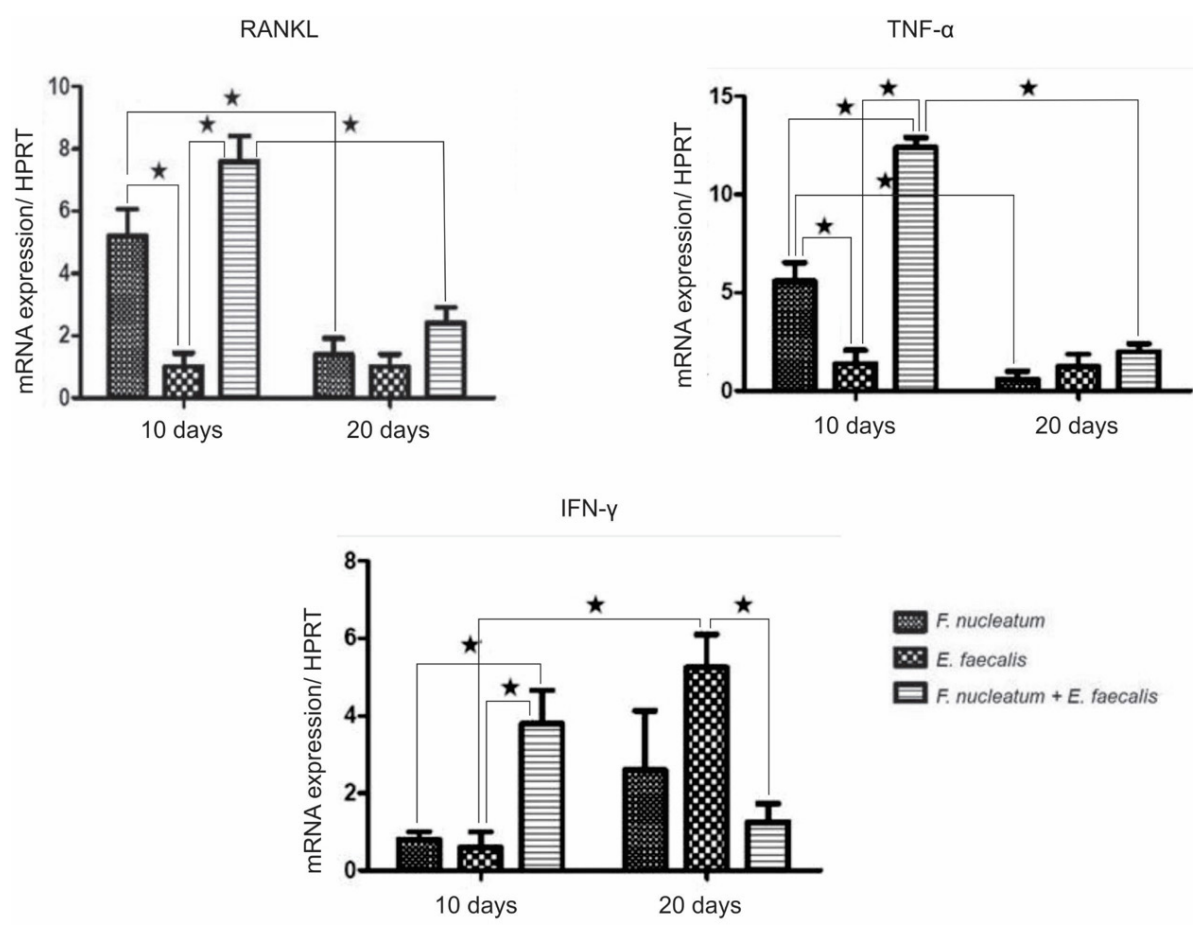

Figure 1. mRNA expression of IFN- $\gamma$, TNF- $\alpha$, and RANKL cytokines in periapical tissues 10 and 20 days after the surgical procedure analyzed by real-time PCR. Relative mRNA expression levels quantified by comparison with the internal control (HPRT). Data expressed as mean \pm SE for three independent experiments, each with ten mice per group. The star indicates $\mathrm{p}<0.05$. levels surpassed a fixed threshold. Expression levels were calculated using the $\Delta \Delta \mathrm{Ct}$ method. The $\mathrm{Ct}$ values are expressed as mean of two independent measurements, and the expression levels of mRNA for all samples are expressed as the ratio between the expression of the genes of interest and the expression of HPRT. All data were analysed using the SPSS statistical program (SPSS Inc., Chicago, IL, USA).

\section{Data Analysis}

The Kruskal-Wallis test was used due the high variation coefficient (VC), above 30\%; this characterized the unstable and heterogeneous sample. Furthermore, several variables showed an asymmetric distribution.

\section{Results}

Genetic expression of RANKL was observed at both evaluation periods (10 and 20 days). F. nucleatum, in mono- (Group 1) or bi-association with E. faecalis (Group 3) induced statistically higher RANKL expression on day 10 than day 20. On day 10, F. nucleatum, in mono- or biassociation with $E$. faecalis, induced higher expression of RANKL than $E$. faecalis alone $(\mathrm{p}<0.05)$. However, on day 20 , there was no difference among the three groups.

Similarly to that of RANKL, TNF- $\alpha$ expression (Fig. 1) was significantly higher on day 10 post-inoculation than on day 20 in F. nucleatum mono-infection or bi-infection with $E$. faecalis. On day 10 , the gene expression of TNF- $\alpha$ in Groups 1 and 3 was significantly higher than that in Group 2 (E. faecalis). However, there was no difference among the groups on day 20. E. faecalis induced a baseline cytokine expression in both periods of evaluation.

$\mathrm{Bi}$-association induced increased IFN- $\gamma$ expression on day 10 compared with both mono-infections at same time. Interestingly, E. faecalis mono-infection induced a significant increase in the expression of IFN- $\gamma$ on day 20 compared to day 10 (Group 2); this increase in expression was also observed in bi-association on day 20 (Group 3).

Mono or bi-associated F. nucleatum (Group 1 and 3) induced a statistically 
significant increase in TGF- $\beta$ expression from day 10 to day 20 . Additionally, a significant overexpression of TGF- $\beta$ was observed on day 20 in bi-association samples compared with those of both mono-infections.

Regulatory cytokine IL-10 expression was significantly up-regulated on day 20 in F. nucleatum infections (Fig 2) compared to day 10; this was also true of E. faecalis mono-association and bi-association during the same time.

\section{Discussion}

Previous studies have used animal models to assess the multiple aspects involved in the periradicular disease pathogenesis $(1,11$,$) . The tested hypothesis in the present$ study was that different infections could trigger particular immune responses in the development of periapical lesions. Using two reference strains, F. nucleatum and E. faecalis, via mono or bi-association, was assessed the immune response in periapical tissues surrounding the infections. Bi-association was chosen since some strict anaerobic bacteria may be more powerful in inducing apical periodontitis when associated with other anaerobic or facultative microorganisms (1). Additionally, it was also shown that both strains associated here did not produce antagonistic factors against each other (12). Moreover, as demonstrated in many laboratories that use rodent models (6), after inducing experimental root canal infection, periapical bone destruction starts 7 days later. From days 7 to 20, rapid destruction occurred followed by slower bone resorption. Based on these findings, were defined both evaluation periods ( 10 and 20 days) of this study. Pro-inflammatory (RANKL, TGF- $\alpha$ e IFN- $\gamma$ ) and regulatory (IL-10 e TGF- $\beta$ ) cytokine expression were assayed by qPCR.

RANKL is a cytokine whose main role in bone physiology is to stimulate osteoclast differentiation and activation, and to inhibit cell apoptosis (7). This study observed that F. nucleatum, in mono (Group 1) or bi- association (Group
3), induced higher RANKL expression on day 10 compared to day 20. These results suggest that the RANKL expression increases in the early stages of periapical lesion expansion; furthermore, E. faecalis does not interfere with this process. Although it has been related to a plethora of unidentified microorganisms, both in periapical lesions (7) and the experimental induction of periodontitis (13), RANKL is present in large amounts in lesions in the early stages of development. Blocking of RANKL by OPG (osteoprotegerin) during the experimental induction of periodontal disease decreases alveolar bone loss, as previously shown (14).

TNF- $\alpha$ has activities that affect multiple aspects of the cell migration process, including the induction of adhesion molecules and production of chemokines (15). In this study, it was observed that $F$. nucleatum, in mono or bi-association with E. faecalis, induced an increase in TNF- $\alpha$ expression on day 10 compared to day 20 . Furthermore, it was determined that $E$. faecalis did not interfere in this expression or the expression of RANKL. These results are similar to those of other studies that demonstrated increased levels of TNF- $\alpha$ and RANKL in gingival fluid and diseased periodontal tissue $(15,16)$. Garlet et al. (16) induced periodontal disease in TNF- $\alpha$ p55 deficient mice and identified a concomitant decrease in the expression of RANKL; consequently, there was a reduction in alveolar bone loss. In this experiment, F. nucleatum alone or in association with $E$. faecalis also produced the genetic expression of this cytokine in the evaluated periapical tissues. The lipoteichoic acid isolated from $E$. faecalis and other Gram-positive bacteria strains also stimulate the release of TNF- $\alpha$ by leukocytes in periapical lesion samples, as demonstrated by in vitro studies (17). In the present research, despite the results of $E$. faecalis mono-infection, which show induced basal expression of TNF- $\alpha$ at both time points (10 and 20 days), the expression on day 10 was significantly lower than the one observed for $F$. nucleatum alone or in association
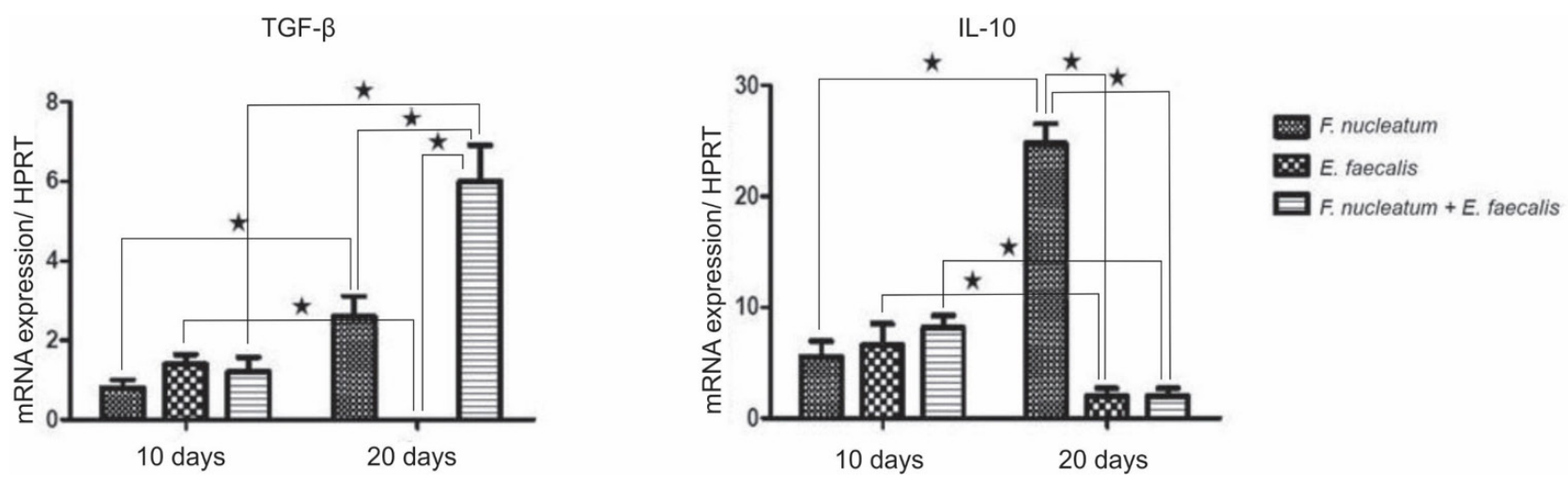

Figure 2. mRNA expression of TGF- $\bigotimes$, and IL-10 cytokines in periapical tissues 10 and 20 days after the surgical procedure analyzed by realtime PCR. Relative mRNA expression levels quantified by comparison with the internal control (HPRT). Data expressed as mean \pm SE for three independent experiments, each with ten mice per group. The star indicates $\mathrm{p}<0.05$. 
with E. faecalis.

IFN- $\gamma$ is a type 1 cytokine that plays an important role in the activation of cell phagocytosis; specifically, it induces the proinflammatory production of cytokines and chemokines (18). Its presence is high in periodontal lesions and it is related to the periradicular response progression in severe forms (19). In this study, the genetic expression of IFN- $\gamma$ on day 10 before microbial bi-association inoculation was significantly higher than in F. nucleatum and $E$. faecalis mono-infection. There was a decrease of IFN- $\gamma$ expression induced by the bi-infection on day 20, but there was a significant increase in their respective expressions in response to $E$. faecalis. Similarly, Jiang et al. (19) demonstrated that other Gram-positive pathogens, such as Streptococcus mutans, stimulated the synthesis of proinflammatory cytokines. Conflicting results in which $G$. morbillorum reduces the expression of cytokines IL-12 and IFN- $\gamma$ in cell culture supernatant have also been reported (1). IFN- $\gamma$ is a potent macrophage activator, which leads to increased expression in IL-1 and TNF- $\alpha$ by these cells, modulating RANKL and osteoclastogenesis in periapical inflammatory diseases (20). The increase in the levels of IFN- $\gamma$ on day 10 in response to bi-infection agrees with these findings. The RANKL and TNF- $\alpha$ were found in high concentrations during the same period and under the same conditions. On day 20, when the decrease in the expression results. However, an inverse effect of IFN- $\gamma$, that it can inhibit osteoclastogenesis has been described (21).

In normal conditions, proinflammatory mechanisms should be controlled because they prevent excessive periradicular tissue destruction. IL-10 and TGF- $\beta$ are both important immunoregulatory cytokines (22). IL-10 antagonizes the proinflammatory effects, inhibiting the mRNA transcription subgroup of cytokines, which acts as a negative feedback mechanism (22). According to Colic et al. (22), the increased levels of IL-10 induced by F. nucleatum mono-infection on day 20 are correlated with the low expression of proinflammatory RANKL, TNF- $\alpha$ and IFN- $\gamma$ cytokines during the same period; the low expression of IL-10 on day 10 is associated with increased expression of proinflammatory cytokines. These findings are similar to the results of a previous study, which have demonstrated high levels of IL-10 production in inflammatory cells challenged by Gram-negative bacteria (23). However, the proinflammatory response modulation induced by biassociation on day 20 is not associated with IL-10, but with TGF- $\beta$; this is primarily due to the fact that overexpression during this period is correlated with the expression of RANKL and TNF- $\alpha$. TGF- $\beta$ is a pleiotropic cytokine that regulates growth, differentiation and cell matrix production. Furthermore, TGF- $\beta$ is a potent immunosuppressive agent that controls the proinflammatory factors related to transcription, like IL-1 $\beta$ and TNF- $\alpha$ (24). Interestingly, the late proinflammatory response observed in the $E$. faecalis mono-infection with high IFN- $\gamma$ expression on day 20, did not exhibit the negative regulatory effects of cytokines IL-10 or TGF- $\beta$. IFN- $\gamma$ is an important cytokine that mediates $B$ cell isotype changes and leads to an increase in $\lg G 2$ production (25). These regulatory effects are also responsible for the reduced RANKL and TNF- $\alpha$ expression during the same period, which invariably lead to an increase in the microbial clearance at the site.

Finally, it is important to highlight the fact that regulatory cytokines, including $\mathrm{IL}-10$ and TGF- $\beta$, act directly on osteoclastogenesis. In absence of IL-10, there is reduction in osteoblast and osteoclast expression. In the presence of these cytokines, it is believed that the RANK/ RANKL system modulation leads to the induction of OPG production (26). As for TGF- $\beta$, its levels in active periapical lesions correlate negatively with RANKL; this may have a protective role against tissue destruction.

This study demonstrated that the genetic expression of periapical cytokines depends on the bacterial community that colonizes root canal systems: mono-infection of $F$. nucleatum promoted high levels of RANKL and TNF- $\alpha$ expression. Moreover, the higher levels of RANKL, TNF- $\alpha$ and IFN- $\gamma$ were observed when associated with $E$. faecalis. Similarly, the mono-infection of $F$. nucleatum seems to be modulated by IL-10 and TGF- $\beta$ on day 20 , while the biassociation may be regulated by TGF- $\beta$ at the same time.

\section{Resumo}

0 objetivo deste trabalho foi avaliar a expressão gênica de citocinas próinflamatórias (RANKL, TNF- $\alpha$ e IFN- $\gamma$ ) e regulatórias (TGF- $\beta$ e IL-10) em resposta à infecção experimental por Fusobacterium nucleatum (ATCC 10953) e Enterococcus faecalis (ATCC 19433) como mono-infecção ou em bi-associação. F. nucleatum e E. faecalis foram inoculados no sistema de canais radiculares de camundongos Balb/c, tanto isoladas como em bi-associação. Os animais foram sacrificados em 10 e 20 dias após a infecção, e os tecidos periapicais foram coletados. As expressões do mRNA das citocinas RANKL, TNF- $\alpha$, IFN- $\gamma$, TGF- $\beta$ e IL-10 foram analisadas por meio do real-time PCR. 0 teste de Kruskal-Wallis foi utilizado para análise estatística. A mono-infecção com F. nucleatum induziu alta expressão de RANKL e TNF- $\alpha$, enquanto sua modulação ocorreu devido à IL-10. A alta expressão de IFN $-\gamma$ no dia 20 foi regulada positivamente por $\mathrm{E}$. faecalis e RANKL; TNF- $\alpha$ foi regulada positivamente por um mecanismo independente via IL-10 e TGF- $\beta$. A bi-associação (F. nucleatum e E. faecalis) estimulou uma alta expressão de RANKL, TNF- $\alpha$ e IFN- $\gamma$, que parece ser modulada por TGF- $\beta$ após 20 dias. A expressão gênica de citocinas pró-inflamatórias foi mais proeminente nos estágios iniciais da infecção periapical experimental, com concomitante redução no período tardio. Este fenômeno pode ser regulado por IL-10 e TGF- $\beta$ em uma condição de infecção especifica.

\section{Acknowledgements}

This work was supported by Fundação de Amparo à Pesquisa do Estado de Minas Gerais (FAPEMIG), Coordenação de Aperfeiçoamento de Pessoal de Nivel Superior (CAPES), and Conselho Nacional de Desenvolvimento 
Cientifico e Tecnológico (CNPq). The authors deny any conflicts of interest. The authors wish to thank the postgraduate program at the School of Dentistry of UFMG. APRS and LOV are CNPq fellows.

\section{References}

1. Ribeiro-Sobrinho AP, de Melo Maltos SM, Farias LM, de Carvalho MA, Nicoli JR, de Uzeda M, et. Al.. Cytokine production in response to endodontic infection in germ-free mice. Oral Microbiol and Immunol 2002;17:344-353.

2. Socransky SS, Haffajee AD, Cugini MA, Smith C, Kent RL Jr. Microbial complexes in subgingival plaque. J Clin Periodontol 1998;25:134-144.

3. Sundqvist $\mathrm{G}$, Figdor $\mathrm{F}$. A big role for the very small I- understanding the endodontic microbial flora. Austr Dent J 2007;52:S38-51.

4. Jiang J, Zuo J, Hurst IR, Holliday LS. The synergistic effect of peptidoglycan and lipopolysaccaride on osteoclast formation. Oral Surg Oral Med Oral Pathol Oral Radiol Endod 2003;96:738-743.

5. Maciel KF, Neves de Brito LC, Tavares WLF, Moreira G, Nicoli JR, Vieira LQ, et al.. Cytokine expression in response to root canal in gnotobiotic mice. Int Endod J 2012;45:354-362.

6. Stashenko $\mathrm{P}, \mathrm{Yu} \mathrm{SM}$, Wang $\mathrm{CY}$. Kinetics of immune cell and bone resorptive responses to endodontic infections. J Endod 1992;9:422426.

7. Kawashima N, Suzuki $N$, Yang G, Ohi C, Okuhara S, Nakano-Kawanishi $H$, et al.. Kinetics of RANKL, RANK and OPG expressions in experimentally induced rat periapical lesions. Oral Surg Oral Med Oral Pathol Oral Radiol Endod 2007;103:707-711.

8. Horiba N, Maekawa Y, Abe Y, Ito M, Matsumoto T, Nakamura $H$, et. al.. Cytotoxicity against various cell lines of lipopolysaccharides purified from Bacteroides, Fusobacterium and Veillonella isolated from infected root canals. J Endod 1989;15:530-534.

9. Wang S, Liu K, Seneviratne CJ, Li X, Cheung GS, Jin L, et al.. Lipoteichoic acid from an Enterococcus faecalis clinical strain promotes TNF- $\alpha$ expression through the NF-KB and p38 MAPK signaling pathways in differentiated THP-1 macrophages. Biomed Rep 2015;3:697-702.

10. Moller AJ. Microbiological examination of root canals and periapical tissues of human teeth. Methodological studies. Odontol Tidskr 1966;74(Suppl.):1-380.

11. Silva MJ, Sousa LM, Lara VP, Cardoso FP, Júnior GM, Totola AH, et al.. The role of iNOS and PHOX in periapical bone resorption. J Dent Res 2011;90:495-500.

12. Sobrinho AP, Barros MH, Nicoli JR, Carvalho MA, Farias LM, Bambirra $E A$, et al.. Experimental root canal infections in conventional and germfree mice. J Endod 1998;24:405-408.

13. Garlet GP, Cardoso CR, Silva TA, Martins W Jr, Silva JS. Expression of suppressors of cytokine signaling in diseased periodontal tissues: a stop signal for disease progression? J Periodontal Res 2006;41:580-584

14. Jin $\mathrm{Q}$, Cirelli JA, Park CH, Sugai JV, Taba M Jr, Kostenuik PJ, et al.. RANKL inhibition through osteoprotegerin blocks bone loss in experimental periodontitis. J Periodontol 2007;78:1300-1308.

15. Graves D. Cytokines that promote periodontal tissue destruction. J
Periodontol 2008:79:1585-1591.

16. Garlet GP, Cardoso CR, Campanelli AP, Ferreira BR, Avila-Campos $\mathrm{MJ}$, Cunha FQ, et al.. The dual role of p55 tumour necrosis factoralpha receptor in Actinobacillus actinomycetemcomitans-induced experimental periodontitis: host protection and tissue destruction. Clin Exp Immunol 2007;147:128-138.

17. Kayaoglu G, Ørstavik D. Virulence factors of Enterococcus faecalis: relationship to endodontic disease. Crit Rev Oral Biol Med 2004;15:308220.

18. Dutzan $N$, Vernal $R$, Hernandez $M$, Dezerega $A$, Rivera 0 , Silva $N$, et al.. Levels of interferon-gamma and transcription factor T-bet in progressive periodontal lesions in patients with chronic periodontitis. J Periodontol 2009;80:290-296.

19. Jiang Y, Magli L, Russo M. Bacterium-dependent induction of cytokines in mononuclear cells and their pathologic consequences in vivo. Infec Immun 1999;67:2125-2130.

20. Repeke CE, Ferreira SB Jr, Claudino M, Silveira EM, de Assis GF, AvilaCampos MJ, et al.. Evidences of the cooperative role of the chemokines CCL3, CCL4 and CCL5 and its receptors CCR1+ and CCR5+ in RANKL+ cell migration throughout experimental periodontitis in mice. Bone 2010;46:1122-1130.

21. Ji S, Shin JE, Kim YS, Oh JE, Min BM, Choi Y.. Toll-like receptor 2 and NALP2 mediate induction of human beta-defensins by Fusobacterium nucleatum in gingival epithelial cells. Infec Immun 2009;77:10441052.

22. Colic M, Gazivoda D, Vucevic D, Vasiliji $S$, Rudolf $R$, Luki冈 A. Proinflammatory and immunoregulatory mechanisms in periapical lesions. Mol Immunol 2009;47:101-113.

23. Rezende TM, Vargas DL, Cardoso FP, Sobrinho AP, Vieira LQ. Effect of mineral trioxide aggregate on cytokine production by peritoneal macrophages. Int End J 2005;38:896-903.

24. Steinsvoll S, Halstensen TS, Schenck K. Extensive expression of TGFbeta 1 in chronically-inflamed periodontal tissue. J Clin Periodontol 1999;26:366-373.

25. Al-Darmaki $S$, Knightshead $K$, Ishihara $Y$, Best $A$, Schenkein HA, Tew $J G$, et al.. Delineation of the role of platelet-activating factor in the immunoglobulin G2 antibody response. Clin Diag Lab Immunol 2004;11:720-728.

26. Claudino M, Garlet TP, Cardoso CR, de Assis GF, Taga $R$, Cunha FQ, et al.. Down-regulation of expression of osteoblast and osteocyte markers in periodontal tissues associated with the spontaneous alveolar bone loss of interleukin-10 knockout mice. Europ J Oral Sci 2010;118:19-28.

Received March 28, 2016 Accepted June 8, 2016-11-18 